\title{
CALCIUM AND PHOSPHORUS METABOLISM IN OSTEOMALACIA. XI. THE PATHOGENETIC RÔLE OF PREGNANCY AND RELATIVE IMPORTANCE OF CALCIUM AND VITAMIN D SUPPLY
}

\author{
By S. H. LIU, H. I. CHU, H. C. HSU, H. C. CHAO, and S. H. CHEU \\ (From the Department of Medicine, Peiping Union Medical College, Peiping, China)
}

(Received for publication November 6, 1940)

Though osteomalacia is fundamentally a disease due to vitamin D deficiency and dietary calcium shortage, it is made manifest or aggravated by a host of predisposing factors among which the processes of reproduction deserve special attention. Pregnancy and lactation, albeit normal physiological phenomena, make additional demands upon the calcium and phosphorus supplies of the mother, so that diets adequate under ordinary circumstances become deficient during reproductive activity. Our previous reports $(1,2)$ on the metabolic data of eight Chinese lactating women, with or without osteomalacia, have demonstrated that the drain of lactation varies with the stage of lactation and the quantity of milk secretion. During late lactation when milk yield is small, positive balances in calcium and phosphorus can usually be secured with the addition of vitamin $D$, even when the intake of minerals is moderate or limited. However, in early lactation, especially if abundant, the loss of calcium in milk is so great that a high intake of calcium is essential in addition to adequate vitamin D supply to prevent depletion of skeletal store. Therefore, if nursing is maintained on dietaries deficient in vitamin D and calcium, as is often the case in China, skeletal demineralization will inevitably result.

A similar chain of events probably occurs in pregnancy. In this part of the reproductive cycle nutritional requirements are increased to provide building material for the fetus and its adnexa and for the development of maternal tissues such as the uterus, mammary glands and other organs, in order to meet the demands of labor and parturition and to prepare for milk secretion. The quantitative aspects of the question are not accurately known, but may be approached from the chemical analysis of fetuses at term and at various ages. Givens and Macy (3) and Macy and Hunscher (4) have shown the average calcium content of the human fetus at birth to be about 21 to 23 grams; Coons et al. (5) give similar estimates, while McIlroy (6) puts the figure considerably higher, namely, at 30 grams. The average phosphorus content of the fetus at term is approximately 14 grams. The whole subject has been reviewed by Macy and Hunscher (4) and by Garry and Stiven (7). It is generally accepted that the mineral needs of the fetus are insignificant during the first four months, but from then on they increase rapidly so that about two-thirds of the total are deposited during the last three months. Therefore, a minimum of $200 \mathrm{mgm}$. of calcium and $100 \mathrm{mgm}$. of phosphorus per day should be retained by the mother during the last three months of pregnancy in order to satisfy the fetal requirement without drawing upon the maternal mineral store. These estimates, though they are from Western sources, may serve to indicate the magnitude of drain upon the maternal tissues during pregnancy if living conditions and dietaries are incapable of supporting such a degree of mineral retention, as they appear to be frequently in China.

The primary purposes of the work to be reported in the present communication are to observe the calcium, phosphorus and nitrogen metabolism of patients with osteomalacia during pregnancy, to compare it with that of individuals without skeletal decalcification and to assess the relative importance of vitamin $\mathrm{D}$, calcium and phosphorus intake in securing adequate mineral balances for the added requirements of gestation.

\section{PROCEDURE}

All the patients were studied in the metabolism ward where diets were quantitatively prepared and served, and excreta completely collected. The diets were practically free from vitamin $D$ except those containing small amounts of eggs. They were low in calcium but, when desired, the calcium intake was raised by administering 
S. H. LIU, H. I. CHU, H. C. HSU, H. C. CHAO, AND S. H. CHEU

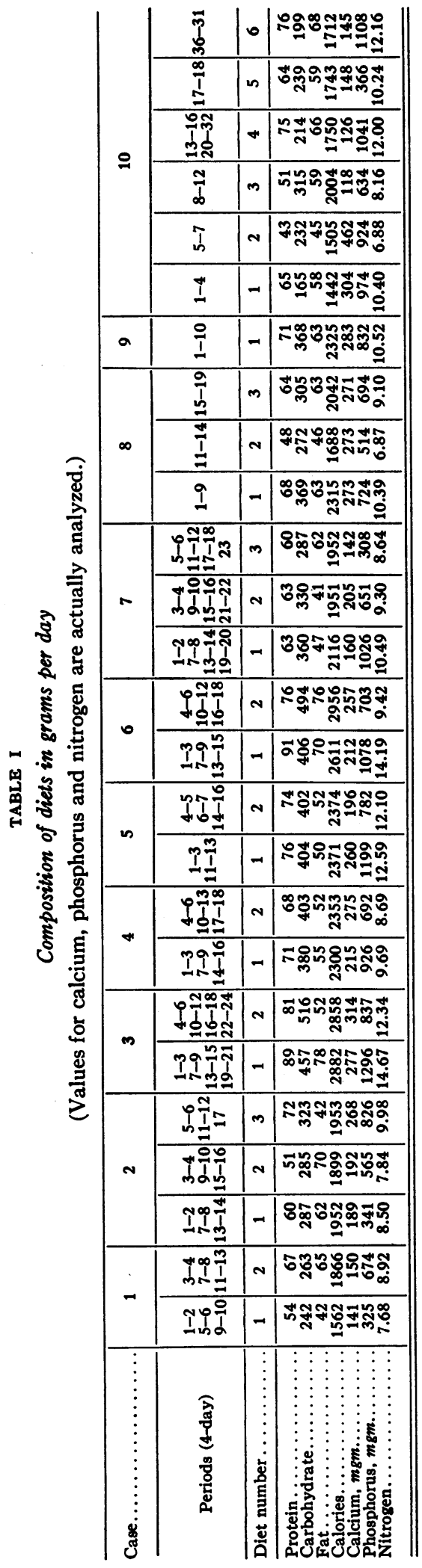

a 7.7 per cent solution of calcium lactate. Distilled water was used for cooking and drinking. The diets were quantitatively consumed with the exception of a few instances. The refused food or vomitus, as the case may be, was then separately analyzed and subtracted from the day's intake. The ward routines and chemical methods for the analysis of food, excreta and serum were described previously $(1,2,8)$. The metabolic periods were four days each.

\section{RESULTS}

This study includes ten Chinese women admitted during various stages of pregnancy. For convenience in presentation, these subjects may be divided into 3 groups according to the condition of their skeletal system. Group I consists of three cases which may be considered, for our purpose, as normal controls, there being no tetany, nor roentgenologic evidence of osteomalacia. Group II contains four subjects, all of whom showed mild osteoporosis, and three of whom had active tetany prior to the metabolic studies. Group III is composed of three patients with advanced osteomalacia, with marked skeletal rarefaction, deformity and fractures. This classification is only approximate because slight depletion of the mineral contents of bones may be passed as normal and small differences in the density of bones from case to case are not detectable by $x$-ray examination. Moreover, the current state of vitamin D nutrition, as shown by the metabolic behavior at the moment, may not always correspond with the condition of the skeleton. However, there is a general parallelism between the skeletal condition and the state of vitamin D store as revealed by metabolic observation in those patients receiving no prior vitamin $\mathrm{D}$ medication.

\section{Group I. Normal}

Case $1, K . C . H$. This was a 19-year-old primipara with normal serum calcium and inorganic phosphorus and without clinical or roentgenologic evidence of skeletal decalcification. She was observed for 13 four-day periods from the end of the eighth month of gestation to term. Two diets, one low in both calcium and phosphorus and the other low in calcium but moderate in phosphorus, alternated with each other every 2 periods. As seen from Figure 1 and Table II, an intake of 141 to $150 \mathrm{mgm}$. calcium (Periods 1 to 4 ) gave 


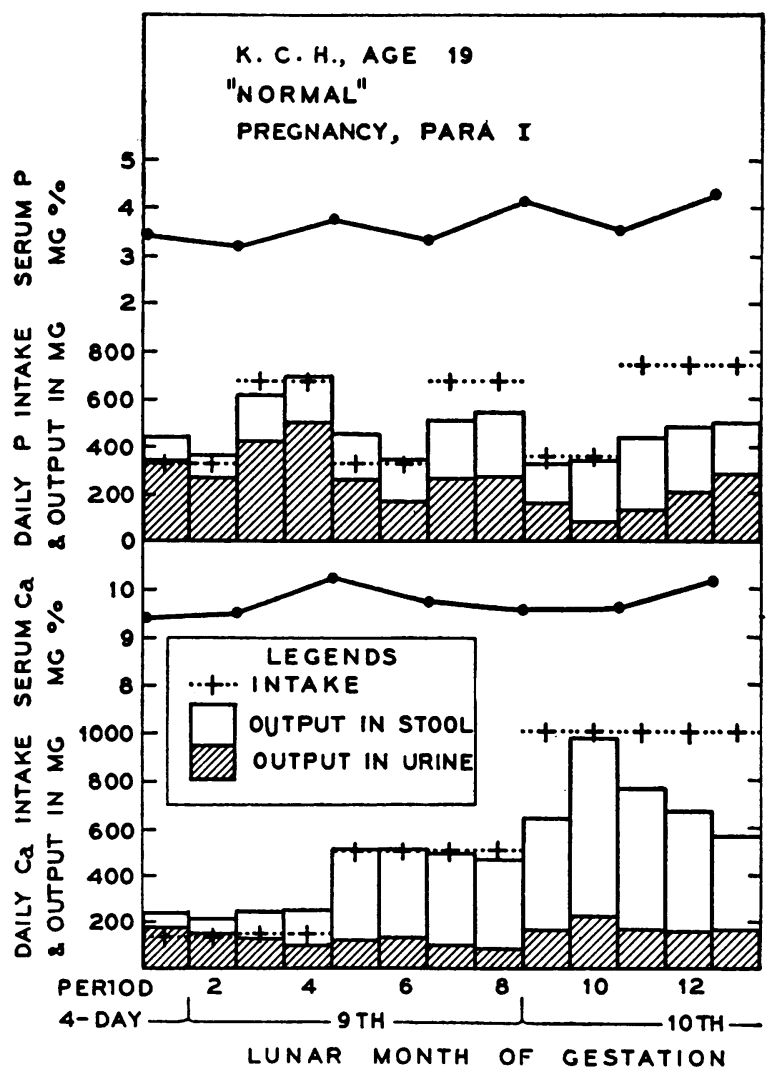

Fig. 1. Case 1. Calcium and Phosphorus Metabolism in a Presumably Normal Individual During the Latter Part of Pregnancy

rise to considerable negative balance, averaging 92 mgm. per day. Raising the intake to $500 \mathrm{mgm}$. (Periods 5 to 8 ) elicited barely even balances. On further augmenting the intake to $1000 \mathrm{mgm}$. (Periods 9 to 13 ), one notices a considerable calcium gain, namely, $284 \mathrm{mgm}$. per day. The calcium balance at a given level of calcium intake was not influenced by the different amounts of phosphorus in the two diets.

However, phosphorus balances were naturally dependent on the phosphorus intake. With an intake of 325 to $358 \mathrm{mgm}$. per day (Periods 1 to 2,5 to 6 and 9 to 10 ), the balances were in the main negative, averaging $44 \mathrm{mgm}$. per day; while an intake of 674 to $741 \mathrm{mgm}$. (Periods 3 to 4 , 7 to 8 and 11 to 13 ) gave rise to considerable gain, namely, about $160 \mathrm{mgm}$. per day. The extent of phosphorus retention at a given level of intake also depended upon the calcium intake. As the latter was gradually raised from 150 to 1000 mgm., there was a progressive diminution of the negative phosphorus balance on the low phosphorus intake and a similar increase of the positive phosphorus balance on the moderate phosphorus intake. This dependence of both calcium and phosphorus balances upon the calcium intake indicates that calcium is a more important limiting factor in the metabolism of the two elements, an observation which has already been described in our previous studies $(9,10)$.

Nitrogen balances remained fairly satisfactory. Serum calcium did not vary significantly throughout the periods of observation, but there was a tendency for serum inorganic phosphorus to fluctuate with the phosphorus intake.

In a previous communication (11), it has been shown that the earliest sign of vitamin $D$ deficiency is a diminution or disappearance of urinary calcium. Increase of stool calcium, decrease of calcium balance and changes in serum calcium and phosphorus follow in that order as the deficiency is allowed to go on. This patient was able to maintain good amounts of calcium in the urine throughout the 13 periods of study. This, together with the consistently normal serum calcium and phosphorus, indicates that the patient had an adequate store of vitamin $\mathrm{D}$ during the studies. Most of that store probably had been acquired prior to admission, as only one of the diets served on the ward contained any vitamin D-containing food, namely egg, and that in small amounts only.

With vitamin $\mathrm{D}$ operative, one may perhaps expect this patient to keep definitely postive balances on an intake of $500 \mathrm{mgm}$. calcium a day. However, only even balances were obtained, and this suggests that her usual intake had been at that level because, as previously pointed out (1), the calcium requirement depends upon, among other factors, the customary dietary level. If $\mathbf{5 0 0}$ $\mathrm{mgm}$. be the usual level of intake, considerably more should be supplied during.pregnancy to meet the fetal needs. In this patient an intake of 1000 mgm. of calcium enabled her to retain a sufficient amount for the added requirement.

Case 2, W. T. Though this 17-year-old primipara had a normal skeleton, her serum calcium and phosphorus were somewhat lower than normal. Metabolic studies extended for 17 periods from the sixth to the eighth lunar month of gestation (Table II). This subject was given 3 diets, all low in calcium, but progressively increased in 
TABLE II

Group 1. Normal calcium, phosphorus and nitrogen metabolism

\begin{tabular}{|c|c|c|c|c|c|c|c|c|c|c|c|c|c|c|c|}
\hline \multirow{2}{*}{ Case } & \multirow{2}{*}{ Date } & \multirow{2}{*}{$\begin{array}{l}\text { Period } \\
\text { 4-day }\end{array}$} & \multirow{2}{*}{$\begin{array}{c}\text { Stage } \\
\text { of } \\
\text { gesta- } \\
\text { tion }\end{array}$} & \multicolumn{4}{|c|}{ Calcium, average daily } & \multicolumn{4}{|c|}{ Phosphorus, average daily } & \multicolumn{4}{|c|}{ Nitrogen, average daily } \\
\hline & & & & Intake & Urine & Stool & Balance & Intake & Urine & Stool & Balance & Intake & Urine & Stool & Balance \\
\hline к.С.H. & $\begin{array}{ll} & 1937 \\
\text { March } & 29-\text { April } 5 \\
\text { April } & 6-13 \\
& 14-21 \\
& 22-29 \\
& \text { 30-May } 7 \\
\text { May } & 8-19\end{array}$ & $\begin{array}{c}1-2 \\
3-4 \\
5-6 \\
7-8 \\
9-10 \\
11-13\end{array}$ & $\begin{array}{c}\text { lunar } \\
\text { months } \\
8-9 \\
9 \\
9 \\
9 \\
10 \\
10\end{array}$ & $\begin{array}{r}m g m . \\
141 \\
150 \\
500 \\
500 \\
1000 \\
1015\end{array}$ & $\begin{array}{l}m g m . \\
164 \\
116 \\
128 \\
97 \\
200 \\
165\end{array}$ & \begin{tabular}{r|}
$m g m$ \\
60 \\
134 \\
376 \\
385 \\
612 \\
502
\end{tabular} & $\begin{array}{l}m g m . \\
-\quad 83 \\
-100 \\
+\quad 4 \\
+\quad 18 \\
+188 \\
+348\end{array}$ & $\begin{array}{r}m g m . \\
325 \\
674 \\
325 \\
674 \\
358 \\
741\end{array}$ & $\begin{array}{c}m g m . \\
306 \\
459 \\
216 \\
268 \\
122 \\
208\end{array}$ & \begin{tabular}{|r|}
$m g m$. \\
96 \\
196 \\
182 \\
259 \\
218 \\
266
\end{tabular} & $\begin{array}{l}m g m . \\
-77 \\
+19 \\
+73 \\
+147 \\
+18 \\
+267\end{array}$ & $\begin{array}{r}\text { grams } \\
7.68 \\
8.92 \\
7.68 \\
8.92 \\
8.45 \\
9.81\end{array}$ & \begin{tabular}{|l} 
grams \\
6.74 \\
7.88 \\
5.92 \\
6.52 \\
6.68 \\
7.68
\end{tabular} & $\begin{array}{l}\text { grams } \\
0.62 \\
0.65 \\
0.70 \\
0.64 \\
0.64 \\
0.65\end{array}$ & $\begin{array}{l}\text { grams } \\
+0.32 \\
+0.39 \\
+1.06 \\
+1.76 \\
+1.13 \\
+1.48\end{array}$ \\
\hline 2. W.T. & 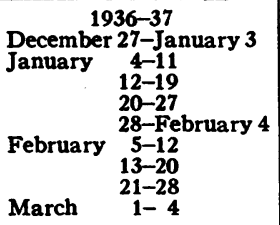 & $\begin{array}{c}1-2 \\
3-4 \\
5-6 \\
7-8 \\
9-10 \\
11-12 \\
13-14 \\
15-16 \\
17\end{array}$ & $\begin{array}{r}6 \\
6-7 \\
7 \\
7 \\
7 \\
8 \\
8 \\
8 \\
8\end{array}$ & $\begin{array}{r}189 \\
192 \\
268 \\
500 \\
500 \\
500 \\
1000 \\
1000 \\
1000\end{array}$ & $\begin{array}{r}39 \\
29 \\
20 \\
57 \\
9 \\
4 \\
20 \\
4 \\
12\end{array}$ & $\begin{array}{l}256 \\
162 \\
220 \\
380 \\
414 \\
444 \\
682 \\
809 \\
698\end{array}$ & $\begin{array}{l}-106 \\
+\quad 1 \\
+\quad 28 \\
+63 \\
+77 \\
+52 \\
+298 \\
+187 \\
+290\end{array}$ & $\begin{array}{r}341 \\
565 \\
826 \\
426 \\
706 \\
1032 \\
426 \\
706 \\
1032\end{array}$ & $\begin{array}{l}327 \\
445 \\
491 \\
206 \\
363 \\
458 \\
378 \\
288 \\
329\end{array}$ & $\begin{array}{l}240 \\
171 \\
258 \\
295 \\
247 \\
388 \\
350 \\
324 \\
333\end{array}$ & $\begin{array}{l}-226 \\
-51 \\
+77 \\
+75 \\
+96 \\
+186 \\
-302 \\
+94 \\
+370\end{array}$ & $\begin{array}{r}8.50 \\
7.84 \\
9.98 \\
10.63 \\
9.80 \\
12.48 \\
10.63 \\
9.80 \\
12.48\end{array}$ & $\begin{array}{l}8.40 \\
7.29 \\
8.57 \\
7.80 \\
7.20 \\
8.21 \\
7.94 \\
8.04 \\
9.31\end{array}$ & $\begin{array}{l}1.01 \\
0.74 \\
0.87 \\
1.13 \\
0.86 \\
1.16 \\
1.26 \\
0.94 \\
1.07\end{array}$ & $\begin{array}{l}-0.91 \\
-0.19 \\
+0.54 \\
+1.70 \\
+1.74 \\
+3.11 \\
+1.43 \\
+0.82 \\
+2.10\end{array}$ \\
\hline L.C.P. & $\begin{array}{ll} & 1940 \\
\text { March } & 11-22 \\
& 23-\text { April 3 } \\
\text { April } & 4-15 \\
& 16-27 \\
& 28-\text { May } 9 \\
\text { May } & 10-21 \\
\text { June } & 22-\text { June 2 } \\
3-14\end{array}$ & $\begin{array}{c}1-3 \\
4-6 \\
7-9 \\
10-12 \\
13-15 * \\
16-18 \\
19-21 \\
22-24\end{array}$ & $\begin{array}{r}7 \\
8 \\
8 \\
8-9 \\
9 \\
9 \\
10 \\
10\end{array}$ & $\begin{array}{r}277 \\
1314 \\
277 \\
1314 \\
277 \\
1314 \\
218 \\
1257\end{array}$ & $\begin{array}{r}3 \\
6 \\
5 \\
7 \\
2 \\
297 \\
21 \\
118\end{array}$ & $\begin{array}{l}138 \\
939 \\
507 \\
820 \\
326 \\
475 \\
128 \\
446\end{array}$ & $\begin{array}{l}+136 \\
+369 \\
-235 \\
+487 \\
-51 \\
+542 \\
+69 \\
+693\end{array}$ & $\begin{array}{r}1296 \\
837 \\
1296 \\
837 \\
1296 \\
837 \\
1277 \\
708\end{array}$ & $\begin{array}{l}544 \\
426 \\
581 \\
437 \\
614 \\
281 \\
552 \\
189\end{array}$ & $\begin{array}{l}463 \\
294 \\
566 \\
223 \\
500 \\
242 \\
504 \\
261\end{array}$ & $\begin{array}{l}+289 \\
+117 \\
+149 \\
+177 \\
+182 \\
+314 \\
+221 \\
+258\end{array}$ & $\begin{array}{l}14.67 \\
12.34 \\
14.67 \\
12.34 \\
14.67 \\
12.34 \\
14.48 \\
12.65\end{array}$ & $\begin{array}{l}9.22 \\
9.66 \\
9.15 \\
8.54 \\
8.89 \\
8.54 \\
8.44 \\
7.91\end{array}$ & \begin{tabular}{|l|}
1.99 \\
1.15 \\
2.29 \\
0.99 \\
1.74 \\
1.28 \\
2.05 \\
1.06
\end{tabular} & $\begin{array}{r}+3.46 \\
+1.53 \\
+3.23 \\
+3.45 \\
+4.04 \\
+2.52 \\
+3.99 \\
+3.68\end{array}$ \\
\hline
\end{tabular}

* Vigantol during Periods 13-16.

phosphorus content. She showed similar metabolic behavior to Case 1 in that negative calcium balances ( $-26 \mathrm{mgm}$. daily) prevailed on an intake of 189 to $268 \mathrm{mgm}$., slightly positive balances (64 mgm. daily) were obtained on an intake of $500 \mathrm{mgm}$. and substantial gain (253 $\mathrm{mgm}$. daily) was secured on an intake of $1000 \mathrm{mgm}$. This is also true with phosphorus balances which varied directly not only with the level of phosphorus intake but also with that of calcium intake.

In comparison with the first case, although this individual exhibited the same degree of conservatism in handling calcium and phosphorus, her store of vitamin D was probably not as adequate, in that the levels of serum calcium and phosphorus were not strictly normal and urinary calcium tended to decrease and disappear even on high intake. Although small amounts of eggs were present in the diet, they were evidently not sufficient to prevent a gradual depletion of the scanty vitamin $\mathrm{D}$ store of the body. However, an intake of $1000 \mathrm{mgm}$. of calcium seemed adequate to fulfill the requirements of pregnancy even if the vitamin $\mathrm{D}$ store was somewhat inadequate.

Case 3, Mrs. L. C. P. This pregnant woman, para IV, was considered normal from the standpoint of her skeleton, and her serum calcium and phosphorus on admission were essentially normal. The plan of observation in this case consisted of 3 periods of low calcium-high phosphorus intake followed by 3 periods of high calcium-moderate phosphorus intake; and this cycle was repeated 3 more times. Therefore, the study covered 24 periods from the seventh month to term. The data are set forth in Figure 2 and Table II. During the first 3 periods on low calcium diet (277 mgm.), the patient exhibited extraordinary ability in maintaining positive balance, averaging 136 mgm. per day. During the next 3 periods on high calcium intake (1296 $\mathrm{mgm}$.), the average positive balance of $369 \mathrm{mgm}$. per day was likewise satisfactory. When the cycle of dietary regime was repeated, though the calcium balance was excellent on high intake (Periods 10 to 12 ), it was markedly negative on low intake (Periods 7 to 9), indicating poor conservation. This, together with a tendency for the serum calcium to fall during the low calcium periods, suggests the wearing out of whatever vitamin $\mathrm{D}$ store the patient might have had at the beginning of the studies.

The supply of vitamin D as Vigantol $1 \mathrm{cc}$. per day (12,000 international units) for Periods 13 to 16 brought about striking changes. From Pe- 
riod 13 to 15, the first 3 periods of Vigantol administration, when the effect of the therapy could hardly be maximal, the calcium balance on low intake began to show favorable influence. In the next 3 periods (Periods 16 to 18 ), while on high calcium intake, the stool calcium was much reduced, and the urinary calcium much increased. As the reduction of calcium in the stool was greater than the increase of urinary calcium, the net balances exceeded those of previous periods on similar high intake. The last 6 periods showed even better calcium retention. During Periods 22 to 24 , the average daily retention was $693 \mathrm{mgm}$., namely, 55 per cent of the intake.

Phosphorus balances remained positive throughout, more so after Vigantol administration. Periods of high phosphorus intake were not necessarily associated with greater phosphorus retention

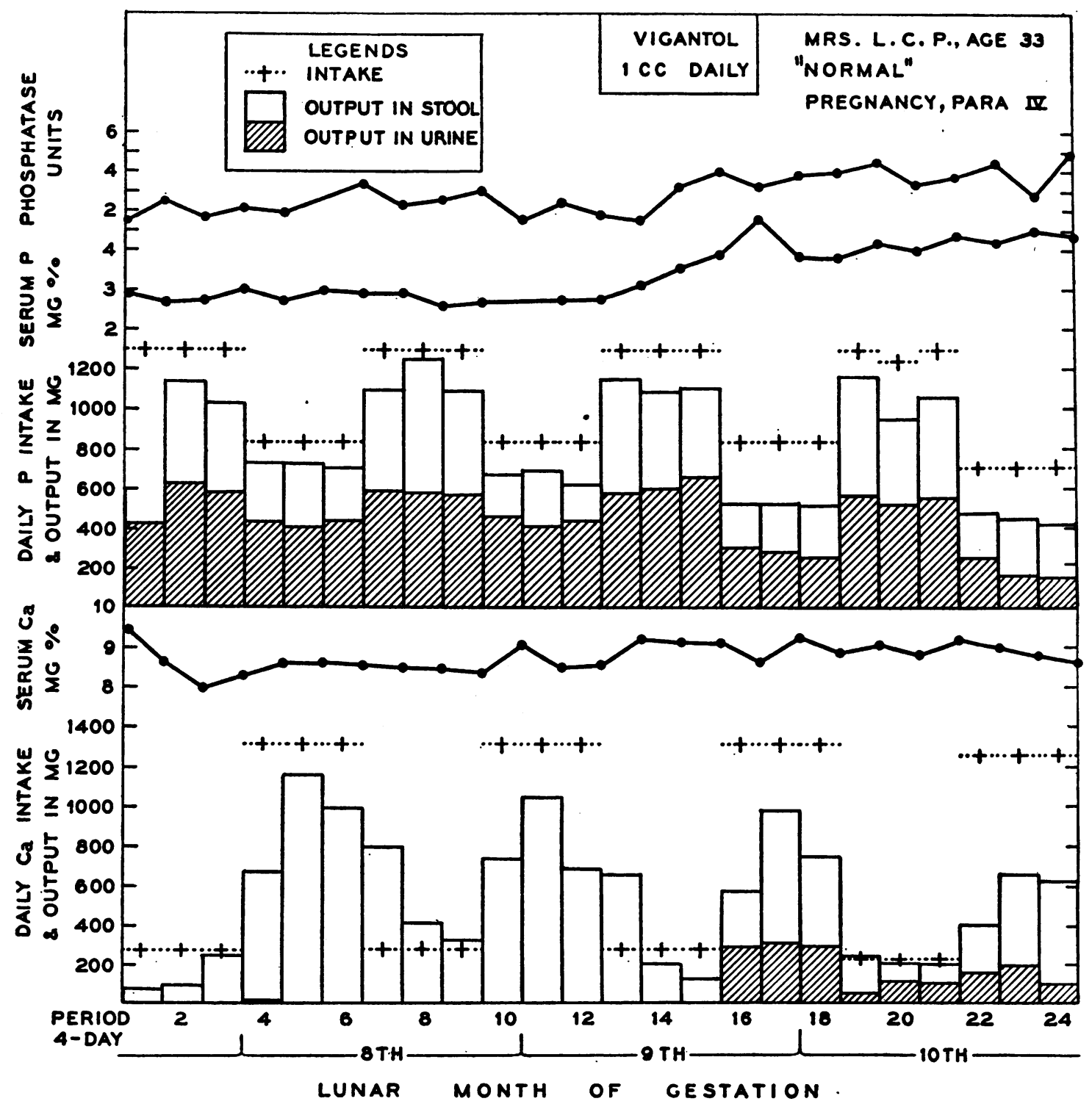

Fig. 2. Case 3. Calcium and Phosphorus Metabolism in a Woman During the latter Part of Pregnancy

Although there was no skeletal decalcification, metabolic behavior showed vitamin D deficiency and responded well to Vigantol therapy. 
than periods of moderate phosphorus intake. In fact, the average daily retention during all the moderate phosphorus periods was slightly more than that during all the high phosphorus periods, undoubtedly because of the limiting effect of low calcium intake during the latter.

Serum calcium and phosphorus both showed a tendency to rise after vitamin D therapy. The rise of serum phosphorus was particularly striking. The nitrogen balance remained excellent throughout.

In comparison with the preceding case, this patient probably had even scantier vitamin D store, because the urinary calcium was absent from the beginning of the experiment. The unusual ability to maintain a positive calcium balance on a low intake during the first 3 periods is to be explained by her previous low calcium intake, which was quite likely the case. In agreement with this supposition is her inability to maintain a balance when the low calcium intake periods were repeated immediately after 3 periods of high intake. However, further depletion of the scanty vitamin D store probably played a contributory rôle in the difference in behavior between the first and second series of low calcium intake periods.

In spite of inadequate vitamin $\mathrm{D}$ store, an intake of approximately $1300 \mathrm{mgm}$. of calcium resulted in adequate retention for the heightened requirements of pregnancy. However, the supply of vitamin $\mathrm{D}$ constitutes a more fundamental solution to the problem. Thus, after Vigantol administration in this case, not only did the urinary calcium appear, the calcium balances on high intake improve and the serum calcium and phosphorus rise to normal, but also positive balances were maintained on low intake. With adequate vitamin $\mathrm{D}$ supply the calcium intake necessary for the requirements of pregnancy could be considerably reduced from 1.3 grams.

Comment. These three patients are alike in possessing normal skeletal mineral store, but they differ in the state of vitamin $\mathrm{D}$ nutrition. The first subject apparently had an adequate store of vitamin $D$ so that 13 four-day periods of a diet low in vitamin $\mathrm{D}$ failed to elicit any evidence of depletion. The average daily calcium retention on high intake was 284 mgm., namely 28 per cent of the intake. The vitamin D store of the second subject was not so adequate, in that signs of de- pletion began to occur after a similar period of study. However, the extent of calcium retention was approximately the same, namely $263 \mathrm{mgm}$. on high intake, or 26 per cent. The third patient showed evidence of depletion even earlier in the course of observation than in Case 2. Still, the extent of calcium retention on high intake remained satisfactory (28 per cent during Periods 4 to 6 and 37 per cent during Periods 10 to 12 ). These observations indicate the frequency of the existence of early or subclinical vitamin $D$ deficiency as in the second and third patients. Such deficiencies cannot be recognized unless detailed metabolic observations are made. In such cases, however, high calcium intake (1 to 1.3 grams) exerts an ameliorative influence and even promotes sufficient calcium retention for the augmented requirements of gestation. On the other hand, vitamin $\mathrm{D}$ is such an economizer of calcium that in the presence of a lower level of calcium, as is the rule here, an adequate supply of vitamin D is imperative, especially during periods of reproductive activity.

\section{Group II. Early or mild osteomalacia}

Case 4, Mrs. L. C. F. Though this 19-year-old primipara had no history or clinical evidence of osteomalacia or tetany, a roentgenologic survey of the skeleton showed slight but definite osteoporosis. Similar to Case 3, a low calcium-high phosphorus regimen alternated with a high calciummoderate phosphorus regimen, covering a total of 18 four-day periods from the eighth month of gestation to term. The first series of 6 periods (Table III) witnessed a slightly positive calcium balance on an intake of $215 \mathrm{mgm}$. per day and a substantial gain (averaging $401 \mathrm{mgm}$. daily or 31 per cent) on an intake of $1275 \mathrm{mgm}$. per day. But, as the studies proceeded, a negative balance prevailed on a low intake, and retention on a high intake steadily diminished so that during the last 2 periods hardly any calcium was retained. This extraordinary behavior indicates the markedly defective intestinal absorption of calcium usually seen in advanced vitamin $\mathrm{D}$ deficiency.

Phosphorus balances were slightly positive throughout, but they tended to be less so with progress of time, corresponding to the behavior of calcium balances. Serum calcium remained constantly between 8 and 9 mgm., while inorganic 
phosphorus, slightly above $3 \mathrm{mgm}$. at the beginning, went down to $2 \mathrm{mgm}$. per cent towards the latter part of the studies. Phosphatase was slightly above normal, mostly between 4 and 6 , but on occasions above 7 Bodansky units.

The point worthy of note in this patient is that, in severe vitamin $\mathrm{D}$ depletion, even an intake as high as $1275 \mathrm{mgm}$. calcium may not enable the patient to maintain a positive balance. This fact may serve to support the contention that adequate vitamin $\mathrm{D}$ plays a more important rôle than high calcium intake in promoting calcium gain.

Case 5, Mrs. S. P. S. This subject, aged 29 years, para IV, may be characterized as a case of mild osteomalacia and latent tetany. Her studies during 7 four-day periods between the fifth and sixth months of gestation showed slightly negative calcium balances on an intake of $260 \mathrm{mgm}$. and an average daily retention of $363 \mathrm{mgm}$. on an intake of 1197 to $1266 \mathrm{mgm}$. (Table III). The same dietary regimen was repeated eleven days after spontaneous abortion of twin fetuses. Both the negative balances in calcium on low intake and the positive balances on high intake (averaging $302 \mathrm{mgm}$. daily) were essentially the same as those during pregnancy. Nor were there pronounced differences in phosphorus retention between the observations during pregnancy and those after delivery. However, there was an unquestionable tendency for both serum calcium and phosphorus to rise after parturition. Whereas before delivery serum calcium varied between 7.14 and 8.47 mgm., its range after delivery was between 7.24 and 8.96 mgm. per cent. Likewise, serum phosphorus, varying between 1.73 and 2.24 during pregnancy, was from 2.11 to $3.47 \mathrm{mgm}$. per cent after delivery.

In this patient moderate vitamin $\mathrm{D}$ deficiency was present, as evidenced by the low serum calcium and phosphorus, the absence of calcium in urine and the failure to retain larger amounts of calcium than she did in the face of mineral shortage in the skeleton.

This patient gave us the opportunity to compare the metabolic behavior of the same individual during pregnancy with her behavior postpartum and uncomplicated by lactation. The results revealed no essential difference between pregnancy at the fifth and sixth months and reproductive rest, as far as the mineral balances were concerned.
Of course, one is aware of the fact that during pregnancy a goodly portion of the retained mineral goes to supply the fetus and its adnexa, while during reproductive rest all remains in the maternal tissues. This is probably the explanation for the tendency of the serum calcium and phosphorus to rise after the termination of the pregnancy without any change in the dietary regimen and without any addition of vitamin $\mathrm{D}$, as shown by this patient.

However, there was no extra demand over and above what was required by the products of conception for growth and development. This is in distinct contrast to the state of affairs in active and early lactation where, it has been demonstrated $(1,2)$, the metabolic processes are so greatly stimulated that calcium has to be supplied not only to cover what is secreted in the milk, but also to cope with this less well-defined factor of stimulation. This is true even in the presence of adequate vitamin D supply. From this we may infer that the drain of pregnancy, as a rule, is not as great as that of lactation.

Case 6, Mrs. C. W. C. This woman of 31 years of age, with mild osteomalacia, cataract and tetany for many years, was studied during the eighth to tenth months of her fourth pregnancy. Prior to the commencement of metabolic observations, calcium gluconate and small amounts of vitamin $\mathrm{D}$ were given so that tetany was controlled. Metabolic behavior for the first 3 periods on a daily intake of $212 \mathrm{mgm}$. of calcium (Table III) was conservative in that positive balances were observed. With the intake raised to 1257 mgm. per day, the daily calcium retention averaged $416 \mathrm{mgm}$. (Periods 4 to 6 ). When the low calcium diet was repeated during Periods 7 to 9 and 13 to 15 , negative balances prevailed, partly because of the preceding high calcium regimen and partly because of beginning depletion of the scanty store of vitamin D acquired prior to the studies. However, with high calcium intake during Periods 10 to 12 and 16 to 18 , the patient had no difficulty in securing adequate positive balances which were, respectively, 324 and $474 \mathrm{mgm}$. per day.

Phosphorus balances were, on the whole, positive, the extent of retention varying with the level of phosphorus intake as well as with that of calcium intake. Serum calcium fluctuated irregu- 
S. H. LIU, H. I. CHU, H. C. HSU, H. C. CHAO, AND S. H. CHEU

TABLE III

Group 2. Early or mild osteomalacia. Calcium, phosphorus and nitrogen metabolism

\begin{tabular}{|c|c|c|c|c|c|c|c|c|c|c|c|c|c|c|c|c|}
\hline \multirow{2}{*}{ Case } & \multirow{2}{*}{\multicolumn{2}{|c|}{ Date }} & \multirow{2}{*}{$\begin{array}{l}\text { Period } \\
\text { 4-day }\end{array}$} & \multirow{2}{*}{$\begin{array}{c}\text { Stage } \\
\text { of } \\
\text { gesta- } \\
\text { tion }\end{array}$} & \multicolumn{4}{|c|}{ Calcium, average daily } & \multicolumn{4}{|c|}{ Phosphorus, average daily } & \multicolumn{4}{|c|}{ Nitrogen, average daily } \\
\hline & & & & & Intake & Urine & Stool & Balance & Intake & Urine & Stool & Balance & Intake & Urine & Stool & Balance \\
\hline L.C..F. & $\begin{array}{l}\text { October } \\
\text { Novembe } \\
\text { December } \\
\text { January }\end{array}$ & 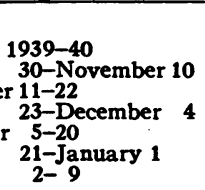 & $\begin{array}{c}1-3 \\
4-6 \\
7-9 \\
10-13 \\
14-16 \\
17-18\end{array}$ & $\begin{array}{c}\text { lunar } \\
\text { months } \\
8 \\
8-9 \\
9 \\
9-10 \\
10 \\
10\end{array}$ & $\begin{array}{r}m g m . \\
215 \\
1275 \\
215 \\
1275 \\
215 \\
1275\end{array}$ & $\begin{array}{r}m g m \\
6 \\
5 \\
5 \\
4 \\
4 \\
4\end{array}$ & $\begin{array}{c}m g m . \\
172 \\
868 \\
319 \\
1066 \\
301 \\
1252\end{array}$ & $\begin{array}{l}\text { mgm. } \\
+37 \\
+402 \\
+109 \\
+205 \\
+90 \\
+19\end{array}$ & $\begin{array}{r}\text { mgm. } \\
926 \\
692 \\
926 \\
692 \\
926 \\
692\end{array}$ & $\begin{array}{l}m g m . \\
369 \\
282 \\
505 \\
288 \\
435 \\
267\end{array}$ & \begin{tabular}{|c|}
$m g m$ \\
426 \\
249 \\
419 \\
308 \\
377 \\
364 \\
\end{tabular} & $\begin{array}{l}\text { mgm. } \\
+131 \\
+161 \\
+\quad 2 \\
+96 \\
+114 \\
+61\end{array}$ & $\begin{array}{r}\text { grams } \\
9.69 \\
8.69 \\
9.69 \\
8.69 \\
9.69 \\
8.69\end{array}$ & $\begin{array}{l}\text { grams } \\
5.64 \\
5.63 \\
6.54 \\
4.65 \\
5.14 \\
4.57\end{array}$ & $\begin{array}{l}\text { grams } \\
2.21 \\
1.58 \\
1.89 \\
1.82 \\
1.59 \\
1.67\end{array}$ & $\begin{array}{l}\text { grams } \\
+1.84 \\
+1.48 \\
+1.26 \\
+2.22 \\
+2.96 \\
+2.45\end{array}$ \\
\hline $\begin{array}{c}\mathbf{5} \\
\text { S.P.S. }\end{array}$ & $\begin{array}{l}\text { February } \\
\text { March }\end{array}$ & $\begin{array}{l}1940 \\
7-18 \\
19-26 \\
27-\text { March 5* } \\
18-29 \\
30-\text { April } 10\end{array}$ & $\begin{array}{c}1-3 \\
4-5 \\
6-7 \\
11-13 \\
14-16\end{array}$ & $\begin{array}{c}5 \\
5-6\end{array}$ & $\begin{array}{r}260 \\
1197 \\
1266 \\
260 \\
1266\end{array}$ & $\begin{array}{l}0 \\
2 \\
2 \\
2 \\
4\end{array}$ & $\begin{array}{l}314 \\
786 \\
948 \\
322 \\
960\end{array}$ & $\begin{array}{r}-54 \\
+409 \\
+316 \\
+64 \\
+302\end{array}$ & $\begin{array}{r}1199 \\
782 \\
753 \\
1199 \\
753\end{array}$ & $\begin{array}{l}500 \\
324 \\
238 \\
660 \\
256\end{array}$ & $\begin{array}{l}576 \\
436 \\
374 \\
494 \\
278\end{array}$ & $\begin{array}{l}+123 \\
+22 \\
+141 \\
+45 \\
+219\end{array}$ & & $\begin{array}{l}7.88 \\
8.10 \\
7.92 \\
9.23 \\
7.58\end{array}$ & $\begin{array}{l}2.06 \\
1.76 \\
1.87 \\
1.52 \\
1.27\end{array}$ & $\begin{array}{l}+2.65 \\
+2.24 \\
+1.98 \\
+1.84 \\
+2.92\end{array}$ \\
\hline c.w. w.c. & $\begin{array}{l}\text { Novembe } \\
\text { December } \\
\text { January }\end{array}$ & $\begin{array}{l}1939-40 \\
\text { er } 19-30 \\
1-12 \\
13-24 \\
25-J \text { January } 5 \\
6-17 \\
18-29\end{array}$ & $\begin{array}{c}1-3 \\
4-6 \\
7-9 \\
10-12 \\
13-15 \\
16-18\end{array}$ & $\begin{array}{c}8 \\
8 \\
8-9 \\
9 \\
9-10 \\
10\end{array}$ & $\begin{array}{r}212 \\
1257 \\
212 \\
1257 \\
222 \\
1257\end{array}$ & $\begin{array}{r}9 \\
21 \\
2 \\
2 \\
5 \\
3\end{array}$ & $\begin{array}{l}145 \\
821 \\
342 \\
931 \\
398 \\
780\end{array}$ & $\begin{array}{l}+58 \\
+415 \\
+132 \\
+324 \\
-181 \\
+474\end{array}$ & $\begin{array}{r}1075 \\
703 \\
1075 \\
703 \\
1123 \\
703\end{array}$ & $\begin{array}{l}588 \\
399 \\
458 \\
281 \\
509 \\
316\end{array}$ & $\begin{array}{l}349 \\
234 \\
413 \\
244 \\
452 \\
283\end{array}$ & $\begin{array}{r}+138 \\
+70 \\
+204 \\
+178 \\
+162 \\
+104\end{array}$ & $\begin{array}{r}14.19 \\
9.42 \\
14.19 \\
9.42 \\
15.06 \\
9.42\end{array}$ & $\begin{array}{l}7.8 \\
7.29 \\
8.23 \\
5.90 \\
9.17 \\
7.12\end{array}$ & $\begin{array}{l}1.93 \\
1.37 \\
1.56 \\
1.25 \\
1.76 \\
1.19\end{array}$ & $\begin{array}{l}+2.48 \\
+0.76 \\
+4.40 \\
+2.27 \\
+4.13 \\
+1.11\end{array}$ \\
\hline w. $\stackrel{7}{\text { E. T. }}$ & $\begin{array}{l}\text { March } \\
\text { April } \\
\text { May } \\
\text { June }\end{array}$ & $\begin{array}{l}1937 \\
13-20 \\
21-28 \\
29-A p r i l 5 \\
6-13 \\
14-21 \\
22-29 \\
30-M a y \\
8-15 \\
16-23 \\
24-31 \\
1-8 \\
9-12\end{array}$ & $\begin{array}{c}1-2 \\
3-4 \\
5-6 \\
7-8 \\
9-10 \\
11-12 \\
13-14 \dagger \\
15-16 \\
17-18 \\
19-20 \\
21-22 \\
23\end{array}$ & $\begin{array}{c}5 \\
5 \\
5-6 \\
6 \\
6 \\
6 \\
7 \\
7 \\
7 \\
7-8 \\
8 \\
8\end{array}$ & $\begin{array}{r}160 \\
205 \\
142 \\
1000 \\
1000 \\
1000 \\
160 \\
205 \\
142 \\
1000 \\
1000 \\
1000\end{array}$ & $\begin{array}{r}48 \\
41 \\
48 \\
70 \\
44 \\
74 \\
18 \\
33 \\
58 \\
188 \\
228 \\
272\end{array}$ & $\begin{array}{r}163 \\
82 \\
62 \\
640 \\
872 \\
710 \\
256 \\
60 \\
46 \\
438 \\
361 \\
370\end{array}$ & $\begin{array}{l}-51 \\
+82 \\
+32 \\
+290 \\
+84 \\
+216 \\
+114 \\
+112 \\
+38 \\
+374 \\
+411 \\
+358\end{array}$ & $\begin{array}{r}1026 \\
651 \\
308 \\
1026 \\
651 \\
308 \\
1026 \\
651 \\
308 \\
1026 \\
651 \\
308\end{array}$ & $\begin{array}{l}402 \\
388 \\
141 \\
128 \\
274 \\
84 \\
280 \\
326 \\
136 \\
136 \\
176 \\
105\end{array}$ & $\begin{array}{l}470 \\
328 \\
176 \\
630 \\
447 \\
242 \\
564 \\
219 \\
140 \\
579 \\
310 \\
208\end{array}$ & $\begin{array}{l}+154 \\
-65 \\
-\quad 9 \\
+268 \\
-70 \\
=18 \\
+182 \\
+106 \\
+32 \\
+311 \\
+165 \\
+\quad 5\end{array}$ & $\begin{array}{r}10.49 \\
9.30 \\
8.64 \\
10.49 \\
9.30 \\
8.64 \\
10.49 \\
9.30 \\
8.64 \\
10.49 \\
9.30 \\
8.64\end{array}$ & $\begin{array}{l}7.95 \\
6.93 \\
6.68 \\
7.52 \\
7.84 \\
6.85 \\
7.05 \\
6.34 \\
5.87 \\
6.68 \\
6.02 \\
5.71\end{array}$ & $\begin{array}{l}1.53 \\
1.27 \\
1.28 \\
1.56 \\
1.20 \\
0.95 \\
1.46 \\
1.34 \\
1.31 \\
1.74 \\
1.40 \\
1.30\end{array}$ & $\begin{array}{l}+1.01 \\
+1.10 \\
+0.68 \\
+1.41 \\
+0.26 \\
+0.94 \\
+1.98 \\
+1.62 ! \\
+1.46 \\
+2.07 \\
+1.88 \\
+1.63\end{array}$ \\
\hline
\end{tabular}

* Abortion March 7.

† Vigantol during Periods 13-23.

larly between 8.12 and 9.73 mgm. per cent, while inorganic phosphorus ranged between 3.45 and 4.09 mgm. per cent. Thus, all the serum inorganic phosphorus values were normal, and most of the serum calcium values were within normal limits. Phosphatase was normal throughout.

Though this patient showed more marked anatomical evidence of previous vitamin D deficiency (osteomalacia, tetany and cataract) than the two preceding subjects, her metabolic behavior exemplified a greater degree of conservatism in that her serum calcium and phosphorus were maintained within normal limits, and her calcium balance on high intake was on the average somewhat higher. This more conservative behavior was most likely the result of the limited supply of vitamin $\mathrm{D}$ received prior to the studies. However, this supply was inadequate to enable her to maintain a balance on low calcium intake and to eliminate significant amounts of calcium in the urine. In other words, there was room for improvement in her metabolic behavior, as in Case 3 , if a more adequate supply of vitamin $D$ had been available to her.

Case 7, Mrs. W.E.T. Similar to the foregoing case, this was one of mild osteomalacia, cataract and tetany of many years' duration. Likewise, this patient received calcium and cod liver oil prior to the metabolic observation for the treatment of her tetany, so that her serum calcium and phosphorus were within normal limits and her metabolic behavior was conservative by the time the studies were begun (Table III). She was given for the first 2 periods a low calciumhigh phosphorus diet, and successively for 2 periods each, two diets similarly low in calcium but progressively lower in phosphorus. On the low calcium intake (142 to $205 \mathrm{mgm}$. per day) the average balance was slightly positive and a considerable proportion of the calcium output was in the urine, showing that vitamin D action was operative. When this series of diets was repeated, but with the calcium intake raised to $1000 \mathrm{mgm}$. a day (Periods 7 to 12 ), the average daily bal- 
ance was $195 \mathrm{mgm}$, and the urinary calcium, though smaller in relation to the total output, was still considerable, showing that her response to high intake was fairly satisfactory by reason of the prior vitamin $\mathrm{D}$ store. However, that this was not the best performance of which the patient was capable was demonstrated by the observations during the subsequent 11 periods in which vitamin $\mathrm{D}$ in daily doses of $1 \mathrm{cc}$. of Vigantol, or 12,000 international units, was given. The first 6 periods on vitamin $\mathrm{D}$ therapy were on low calcium regimen (Periods 13 to 18 ), and no obvious difference was noted in the calcium balance, but, subsequently, during Periods 19 to 23, while on high calcium diet, definite changes took place. Not only did the average daily retention improve to $386 \mathrm{mgm}$., but also the urinary calcium increased greatly. The urinary calcium averaged $221 \mathrm{mgm}$. per day, amounting to 36 per cent of the total output, signifying that intestinal absorption of calcium had improved so that much more calcium was absorbed than could be retained.

Phosphorus balances varied not only with the levels of phosphorus and calcium intake, but also with the state of vitamin $D$ nutrition. All the high phosphorus periods ( 1 to 2,7 to 8,13 to 14 and 19 to 20 ) were associated with considerable positive balance, especially in periods of high calcium intake and after Vigantol therapy. In periods of moderate phosphorus intake (Periods 3 to 4,9 to 10,15 to 16 and 21 to 22 ), the balances, which were negative prior to vitamin $D$ therapy, became positive afterwards. Low phosphorus periods showed slightly negative balances, the degree of phosphorus loss remaining uninfluenced by the high level of calcium intake or by the vitamin $\mathrm{D}$ therapy.

Serum calcium, fairly normal to start with, tended to fall as studies progressed until vitamin $\mathrm{D}$ was given. After this it slowly returned to the initial value. A more definite rise occurred in the level of serum inorganic phosphorus after Vigantol administration.

This patient, though clinically similar to the preceding patient, was somewhat different in metabolic behavior, in that urinary calcium persisted in significant amounts, indicating the presence of a greater store of vitamin D. However, that this store was not the optimum was shown by the improvement in calcium balance, the increase in urinary calcium and the rise in serum phosphorus subsequent to Vigantol administration.

Comment. The four patients in this group are united by the presence of a mild degree of skeletal osteoporosis, but they vary in their metabolic behavior by reason of the varying store of vitamin D. Cases 4 and 5, though presenting less anatomical evidence of vitamin $\mathrm{D}$ deficiency than Cases 6 and 7, were nevertheless more deficient in vitamin $\mathrm{D}$, as shown by the metabolic behavior at the time of observation. Obviously, anatomical evidence and metabolic behavior may not necessarily correspond with each other at a given moment. The former is the result of the extent and duration of previous vitamin $\mathrm{D}$ deficiency, and once the skeleton is decalcified to an extent to be appreciable by roentgenologic examination, a long period of replenishment is required to eradicate the physical evidence of disease. Some of the evidence, such as cataract, may remain permanently, even if the skeletal lesion is all repaired. On the other hand, metabolic behavior is dynamic, readily influenced by such small amounts of vitamin $\mathrm{D}$ as may be introduced by involuntary exposure to sunlight, inclusion in the diet of such items as eggs (11), or the use of limited amounts of cod liver oil for medication, as in Cases 6 and 7. Such factors, often neglected or unrecognized, may make no difference to an individual with an abundant store, but they exert a corrective influence on the metabolic behavior of a patient with vitamin $\mathrm{D}$ deficiency, and therefore must be taken into account in interpreting the metabolic data obtained. Furthermore, such vitamin D supply is usually small and, if not continued, can easily be depleted so that metabolic evidence of vitamin D deficiency appears after a varying number of periods of conservative behavior. This was true of Cases 4 and 6 and would have been true of Case 7 , had vitamin $\mathrm{D}$ been withheld from her. Case 5 was probably deficient in vitamin $D$ from the beginning of the metabolic observations.

Therefore, as a group, these patients all showed mild but definite osseous evidence of previous vitamin D deficiency, but at the time of observation the metabolic behavior indicated a greater current deficiency of the vitamin in Cases 4 and 5 than in Cases 6 and 7, in which some cod liver oil had been given prior to the observations. In severe deficiency (Case 4), high calcium may be of no 
avail in promoting sufficient calcium gain for the fetal needs, although in moderate deficiency (Case 6 ), it is capable of doing so. With adequate vitamin D supply, high calcium intake will enable the patient not only to take care of the demands of pregnancy, but also to store enough calcium for the reparation of her depleted skeleton. Thus, in the treatment of this group of patients, adequate vitamin $\mathrm{D}$ therapy, as well as high calcium intake, is necessary.

Comparison of this group of patients with mild skeletal decalcification with the previous group without bone lesions shows no essential differences in metabolic behavior except insofar as they are related to the state of vitamin $D$ nutrition. In the first group, absence of bone lesions is associated with an early or a mild grade of vitamin $\mathrm{D}$ deficiency, if it is present at all. On the other hand, in the second group where bony decalcification is already recognizable, usually severer grades of vitamin $\mathrm{D}$ deficiency are present if not previously treated. Whatever metabolic differences may exist between the two groups are to be accounted for by the differences in vitamin $\mathrm{D}$ store

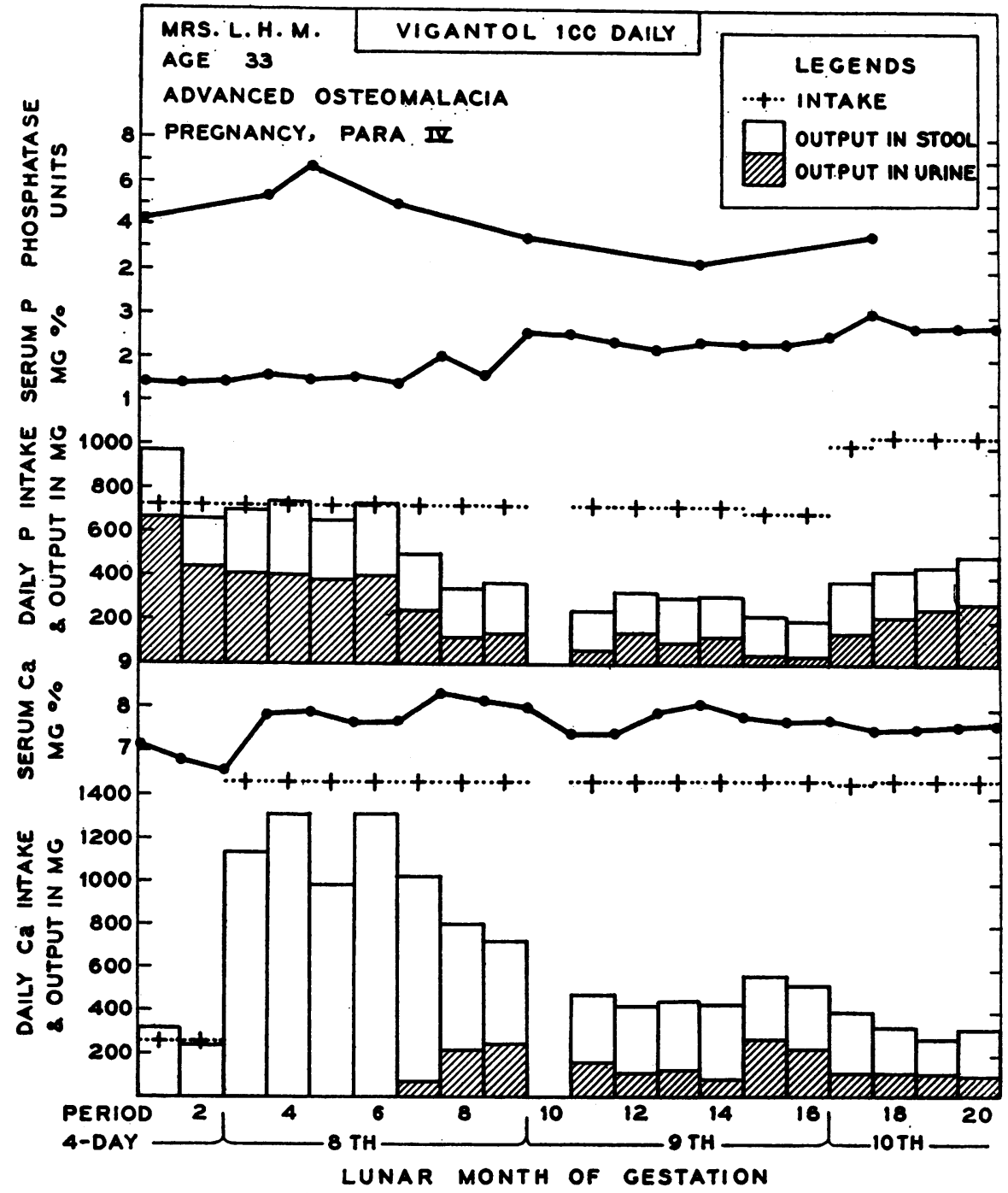

Fig. 3. Case 8. Calcium and Phosphorus Metabolism in Advanced Osteomalacia Showing Remarkable Mineral Retention After Vitamin D Administered During the Latter Part of Pregnancy 
TABLE IV

Group 3. Advanced osteomalacia. Calcium, phosphorus and nitrogen metabolism

\begin{tabular}{|c|c|c|c|c|c|c|c|c|c|c|c|c|c|c|c|}
\hline \multirow{2}{*}{ Case } & \multirow{2}{*}{ Date } & \multirow{2}{*}{$\begin{array}{l}\text { Period } \\
\text { 4-day }\end{array}$} & \multirow{2}{*}{$\begin{array}{c}\text { Stage } \\
\text { of } \\
\text { gesta- } \\
\text { tion }\end{array}$} & \multicolumn{4}{|c|}{ Calcium, average daily } & \multicolumn{4}{|c|}{ Phosphorus, average daily } & \multicolumn{4}{|c|}{ Nitrogen, average daily } \\
\hline & & & & Intake & Urine & Stool & Balance & Intake & Urine & Stool & Balance & Intake & Urine & Stool & Balance \\
\hline $\begin{array}{c}8 \\
\text { L.H.M. }\end{array}$ & \begin{tabular}{|l|l} 
& $1938-39$ \\
November $20-27$ & \\
& $28-$ December 9 \\
December & $10-25$ \\
& $30-$ January 14 \\
January & $15-22$ \\
& 23-February 7
\end{tabular} & $\begin{array}{r}1-2 \\
3-5 \\
6-9 * \\
11-14 \\
15-16 \\
17-20\end{array}$ & $\begin{array}{c}\text { lunar } \\
\text { months } \\
7 \\
8 \\
8 \\
9 \\
9 \\
10\end{array}$ & $\begin{array}{r}m g m . \\
273 \\
1473 \\
1473 \\
1473 \\
1471 \\
1468\end{array}$ & $\begin{array}{r}m g m \\
5 \\
3 \\
140 \\
125 \\
256 \\
110\end{array}$ & $\begin{array}{r}m g m \\
274 \\
1147 \\
835 \\
327 \\
294 \\
225\end{array}$ & $\begin{array}{l}m g m . \\
-\quad 6 \\
+323 \\
+498 \\
+1021 \\
+921 \\
+1133\end{array}$ & $\begin{array}{r}m g m . \\
724 \\
724 \\
724 \\
725 \\
694 \\
1030\end{array}$ & $\begin{array}{r}m g m . \\
556 \\
406 \\
231 \\
114 \\
42 \\
231\end{array}$ & \begin{tabular}{|c|}
$m g m$. \\
265 \\
296 \\
257 \\
188 \\
178 \\
214
\end{tabular} & $\begin{array}{l}m g m \\
-97 \\
+22 \\
+236 \\
+423 \\
+474 \\
+585\end{array}$ & $\begin{aligned} \text { grams } \\
10.39 \\
10.39 \\
10.39 \\
6.87 \\
9.10 \\
9.10\end{aligned}$ & $\begin{array}{l}\text { grams } \\
8.86 \\
7.05 \\
6.42 \\
4.57 \\
5.11 \\
5.87\end{array}$ & $\begin{array}{l}\text { grams } \\
2.00 \\
1.55 \\
1.63 \\
1.24 \\
1.34 \\
1.54\end{array}$ & $\begin{array}{l}\text { grams } \\
-0.47 \\
+1.79 \\
+2.34 \\
+1.06 \\
+2.65 \\
+1.69\end{array}$ \\
\hline W. $\stackrel{9}{\text { H.S. }}$ & 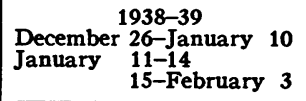 & $\begin{array}{l}1-4 \\
5 t \\
6-10\end{array}$ & $\begin{array}{r}9 \\
10 \\
10\end{array}$ & $\begin{array}{l}1483 \\
1438 \\
1398\end{array}$ & $\begin{array}{r}60 \\
123 \\
181\end{array}$ & \begin{tabular}{|r|}
1268 \\
1360 \\
893
\end{tabular} & $\begin{array}{r}+155 \\
\pm \quad 45 \\
+324\end{array}$ & $\begin{array}{l}832 \\
914 \\
878\end{array}$ & $\begin{array}{l}405 \\
371 \\
337\end{array}$ & $\begin{array}{l}379 \\
381 \\
282\end{array}$ & $\begin{array}{r}+48 \\
+162 \\
+259\end{array}$ & $\begin{array}{l}10.52 \\
10.80 \\
10.33\end{array}$ & $\begin{array}{l}7.47 \\
7.45 \\
6.68\end{array}$ & $\begin{array}{l}1.58 \\
1.77 \\
1.70\end{array}$ & $\begin{array}{r}+1.47 \\
+1.58 \\
+1.95\end{array}$ \\
\hline Y.W.L. & 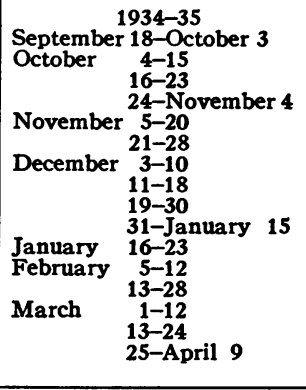 & $\begin{array}{c}1-4 \\
5-7 \\
8-9 \\
10-12 \\
13-16 \\
17-18 \\
20-21 \\
22-23 \ddagger \\
24-26 \\
27-30 \\
31-32 \\
36-37 \\
38-41 \\
42-44 \\
45-47 \\
48-51\end{array}$ & $\begin{array}{c}3-4 \\
4 \\
4 \\
5 \\
5 \\
6 \\
6 \\
6 \\
7 \\
7 \\
8 \\
8 \\
9 \\
9 \\
10 \\
10\end{array}$ & $\begin{array}{r}304 \\
458 \\
118 \\
88 \\
126 \\
1948 \\
1937 \\
1937 \\
1937 \\
1937 \\
1937 \\
1945 \\
1945 \\
1943 \\
1945 \\
1945\end{array}$ & $\begin{array}{r}6 \\
0 \\
4 \\
1 \\
0 \\
233 \\
13 \\
23 \\
91 \\
119 \\
92 \\
202 \\
202 \\
81 \\
51 \\
95\end{array}$ & $\begin{array}{r}124 \\
179 \\
211 \\
65 \\
97 \\
808 \\
1384 \\
1034 \\
888 \\
797 \\
990 \\
1030 \\
1086 \\
1158 \\
1047 \\
1472\end{array}$ & $\begin{array}{r}+174 \\
+279 \\
+\quad 97 \\
+\quad 22 \\
+\quad 907 \\
+540 \\
+880 \\
+958 \\
+1021 \\
+855 \\
+713 \\
+657 \\
+704 \\
+847 \\
+378\end{array}$ & $\begin{array}{r}974 \\
919 \\
634 \\
476 \\
1041 \\
323 \\
1041 \\
1041 \\
1041 \\
1041 \\
1041 \\
1108 \\
1108 \\
1091 \\
1108 \\
1108\end{array}$ & $\begin{array}{r}436 \\
364 \\
281 \\
240 \\
466 \\
22 \\
126 \\
140 \\
42 \\
12 \\
52 \\
12 \\
12 \\
165 \\
214 \\
275\end{array}$ & $\begin{array}{l}285 \\
324 \\
404 \\
264 \\
414 \\
194 \\
494 \\
403 \\
468 \\
422 \\
470 \\
658 \\
736 \\
515 \\
429 \\
605\end{array}$ & $\begin{array}{l}+253 \\
+231 \\
-51 \\
-28 \\
+161 \\
+107 \\
+421 \\
+498 \\
+531 \\
+607 \\
+519 \\
+438 \\
+360 \\
+411 \\
+465 \\
+228\end{array}$ & $\begin{array}{r}10.40 \\
6.88 \\
8.16 \\
6.08 \\
12.00 \\
9.54 \\
12.00 \\
12.00 \\
12.00 \\
12.00 \\
12.00 \\
12.16 \\
12.16 \\
12.00 \\
12.16 \\
12.16\end{array}$ & $\begin{array}{l}8.12 \\
5.91 \\
5.13 \\
3.65 \\
8.31 \\
5.98 \\
8.40 \\
8.38 \\
8.41 \\
8.77 \\
8.82 \\
8.55 \\
9.33 \\
8.89 \\
9.22 \\
9.24\end{array}$ & \begin{tabular}{l|}
0.94 \\
0.93 \\
1.35 \\
1.19 \\
1.28 \\
1.05 \\
1.13 \\
0.93 \\
1.19 \\
1.22 \\
1.23 \\
1.32 \\
1.42 \\
1.21 \\
0.87 \\
1.22
\end{tabular} & $\begin{array}{r}+1.34 \\
+0.04 \\
+1.68 \\
+1.24 \\
+2.41 \\
+2.51 \\
+2.47 \\
+2.69 \\
+2.40 \\
+2.01 \\
+1.95 \\
+2.29 \\
+1.41 \\
+1.90 \\
+2.07 \\
+1.70\end{array}$ \\
\hline
\end{tabular}

* Vigantol during Periods 6-13.

† Vigantol in this period.

$\ddagger$ Vigantol during Periods 22-51.

rather than by the presence or absence of slight bony rarefaction.

\section{Group III. Advanced osteomalacia}

Case 8, Mrs. L. H. M. This subject, aged 33 years, was admitted for study at the seventh month of her fourth pregnancy. She had severe osteomalacia with symptoms dating back eleven years, which was shortly after the birth of her first child. The metabolic data of 20 periods are presented in Figure 3 and Table IV. In the first 2 periods on an intake of $273 \mathrm{mgm}$. of calcium per day, the output, all in the stools, almost balanced the intake. Beginning with Period 3, the intake was raised to $1473 \mathrm{mgm}$. daily. During the first 3 periods on the augmented intake, there was, on the average, a daily retention of $323 \mathrm{mgm}$., or 22 per cent of the intake. This degree of retention may not be abnormally low for a person with a normal skeleton, but for a patient like this with such extensive bony decalcification, together with absence of urinary calcium and low serum calcium and phosphorus, it indicates poor intestinal absorption or severe vitamin $\mathrm{D}$ deficiency. The correctness of this interpretation is shown by her response to Vigantol therapy which was given from Period 6 to 13. From Period 7 onward there was a progressive decrease of stool calcium and, at the same time, the appearance of a considerable amount of calcium in the urine. The average daily retention from Period 11 to 20 was over 1 gram or 70 per cent of the intake. If the last 4 periods, in which the phosphorus intake was raised, were considered alone, the retention averaged $1133 \mathrm{mgm}$. a day or 77 per cent of the intake. The amount retained would enable the patient not only to meet the requirements of pregnancy, but also to repair her depleted skeleton. Her symptoms were considerably improved.

Phosphorus balances were generally parallel with calcium balances. Serum calcium, 6.58 to 7.18 mgm. per cent during the low calcium periods, was raised to a maximum of $7.90 \mathrm{mgm}$. per cent during high calcium periods. After Vigantol administration, a slight further rise occurred, but the highest figure reached was only $8.36 \mathrm{mgm}$. per cent. Serum inorganic phosphorus, $1.45 \mathrm{mgm}$. per cent to start with, remained at this level until vitamin $D$ administration, after which it showed steady elevation, the maximum being 
$3.06 \mathrm{mgm}$. per cent. Serum phosphatase, 4.2 to 6.70 Bodansky units per $100 \mathrm{cc}$., was lowered to 2.35 to 3.54 units after Vigantol therapy.

This patient, who had a severe osteomalacia, showed evidence of vitamin $\mathrm{D}$ deficiency in the early part of the metabolic observations. With vitamin D therapy there resulted remarkable calcium and phosphorus retention. Over and above what was required by the fetus, a substantial part of the retained minerals must have been deposited in the depleted skeleton. In this case, serum calcium and phosphorus failed to rise to perfectly normal levels in spite of adequate vitamin D therapy. Thus it seemed as if the urgent requirement of the skeleton, as well as of the fetus, had to be fulfilled at the expense of the serum concentration of these elements.

Case 9, Mrs. W. H. S. This patient, aged 29 years, was observed for 10 four-day periods during the last part of her fourth pregnancy. While the history of osteomalacia and tetany had been of eleven years' duration, and bony deformities were marked, the degree of skeletal rarefaction was not as extensive as in the preceding case, partly on account of previous treatment. As shown in Table IV, the average calcium balance on an intake of $1483 \mathrm{mgm}$. per day during the first 4 periods was $155 \mathrm{mgm}$., or approximately 10 per cent of the intake. The poor calcium retention, together with low serum inorganic phosphorus and relatively low calcium, indicates definite vitamin D deficiency. Vitamin D in the form of Vigantol $5 \mathrm{cc}$. daily was given for four days during Period 5. The response during the subsequent 5 periods consisted of an increase of the average calcium retention to $324 \mathrm{mgm}$. per day, or 23 per cent of the intake, and a considerable increase of urinary calcium. The response, however, was probably not the best of which the patient was capable in view of the unusual manner in which vitamin $\mathrm{D}$ was given. Large doses of Vigantol given for a few days might not be as efficient as smaller doses spread over a longer period of time, although single massive doses of vitamin $\mathrm{D}$ have been claimed to be effective in the treatment of rickets (12). It is possible that this patient with a lesser degree of skeletal mineral depletion might not require a higher degree of calcium retention than she showed. However, this explanation is not likely, because patients with slight skeletal decalcification (Case 7), or without obvious bone lesions (Case 3 ), exhibited better retention of calcium under adequate vitamin D therapy.

Retention of phosphorus corresponded with that of calcium. Serum calcium was slightly but definitely raised and inorganic phosphorus was markedly elevated after Vigantol therapy.

Case 10, Mrs. Y.W. L. This woman of 43 years of age with severe osteomalacia of four years' duration was observed continuously from the third to the tenth month of her fifth pregnancy. For a year previously she went through detailed metabolic studies during which Vigantol 1 cc. daily $(12,000$ international units of vitamin D per cc.) was given for forty days (ending January 28,1934 ) with considerable improvement in metabolic behavior, as well as clinical symptomatology. Observations during the present pregnancy were begun on September 19, 1935, on a diet containing $304 \mathrm{mgm}$. calcium per day (Figure 4 and Table IV.) On this diet (Periods 1 to 4) more than half of the intake of calcium was retained. This was true of the next diet containing $461 \mathrm{mgm}$. calcium per day (Periods 5 to 7), indicating satisfactory circumstances. Even when the diet calcium was reduced to 88 to $126 \mathrm{mgm}$. per day (Periods 8 to 16), balances, on the whole, were even, showing the remarkable power of conservation of calcium in a patient with osteomalacia when a prior store of vitamin $\mathrm{D}$ had been present.

From Period 17 on, the calcium intake was raised to $1959 \mathrm{mgm}$. per day. During the first 2 periods of high calcium intake, associated with very low phosphorus intake, the calcium retention averaged $907 \mathrm{mgm}$. per day, or 47 per cent of the intake, and the urinary calcium $233 \mathrm{mgm}$. per day, or 22 per cent of the total output. In distinct contrast were the results of Periods 20 and 21 , during which both calcium and phosphorus intakes were high. Here the calcium retention was not as good and the urinary calcium was negligible. It was thought that at this point the patient might be showing an early vitamin $\mathrm{D}$ depletion. Therefore, Vigantol 2 cc. daily was started from Period 22. Subsequently, the calcium balances showed slight improvement and the urinary calcium gradually returned (Periods 22 to 32). Likewise, the phosphorus balances in- 


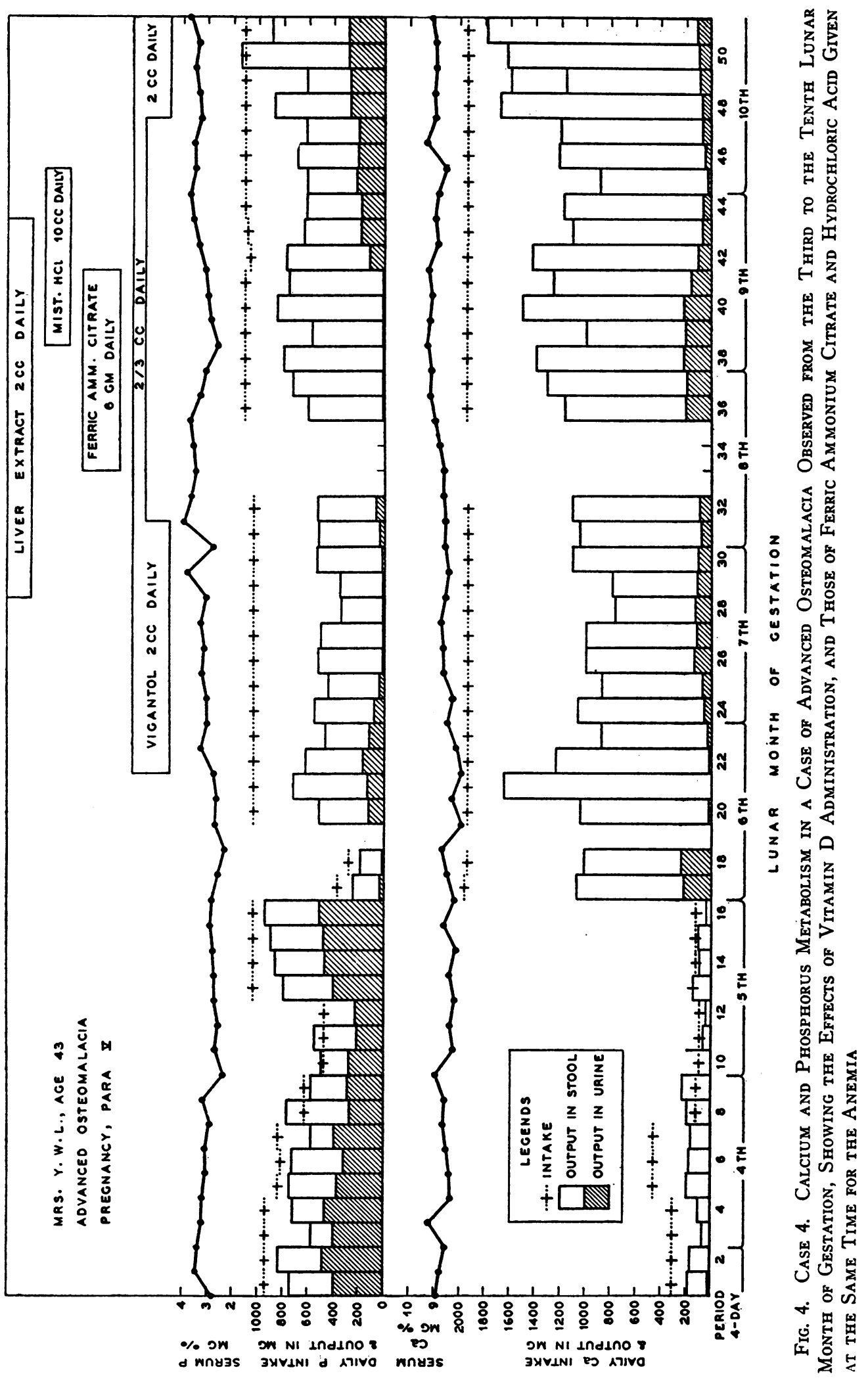


creased correspondingly, mainly at the expense of urinary phosphorus.

In view of the presence of anemia, ferric ammonium citrate, 6 grams daily, was given during Periods 34 to 41 . The anemia did not respond to the iron therapy; both calcium and phosphorus balances were adversely affected by it. The absorption of phosphorus seemed to be particularly impeded by the presence of large amounts of iron in the intestinal tract, probably on account of the formation of insoluble ferric phosphate. Since the absorption of phosphorus was impaired, the calcium balance would decrease mainly on account of a shortage of phosphorus for simultaneous deposition in the bone; hence the undeposited calcium was eliminated in the urine. The discontinuation of iron administration in Period 42 was followed by improved balances both in calcium and in phosphorus, and by decreasing amounts of calcium and increasing amounts of phosphorus in the urine.

The last 4 periods prior to delivery, however, were associated with poorer retention of both calcium and phosphorus. The explanation was not clear, although the discontinuation of hydrochloric acid administration, which had been given during Periods 39 to 45 , might conceivably have removed a factor that promoted absorption. An alternative would be that with prolonged high calcium intake the skeletal store was gradually being replenished, rendering mineral retention less urgent. In support of this supposition, there seemed to be a slight general trend toward decreasing retention throughout the periods of high calcium intake.

Both serum calcium and inorganic phosphorus were within lower limits of normal at the commencement of the observations. Serum calcium varied but slightly except for a tendency to decrease during periods of low calcium intake, and a tendency to increase after vitamin $\mathrm{D}$ addition and after iron therapy. Serum inorganic phosphorus fluctuated more widely. In general, it varied directly with the phosphorus intake. While the latter was maintained on a constantly high intake, vitamin $\mathrm{D}$ administration was associated with a definite rise and iron therapy with a distinct lowering of serum phosphorus.

There are several points of interest in this patient with advanced osteomalacia. First, while vitamin $\mathrm{D}$ was operative a minimal intake of calcium was associated with an even balance, and a high intake with a retention of 40 to 50 per cent. Second, as observations proceeded, there was a tendency to a decreasing retention. This was considered to be related to a gradual replenishment of the skeletal store rather than to any interference attributable to later stages of pregnancy. Finally, the adverse effects of iron on calcium and phosphorus balances deserve attention. While both calcium and phosphorus retention may be reduced under iron therapy, serum phosphorus may fall with a rise in serum calcium. This phenomenon has been utilized in the treatment of hypocalcemia and hyperphosphatemia associated with chronic advanced renal insufficiency (13).

Comment. The three patients in this group, though they were alike in showing marked skeletal decalcification, deformity and fractures, again varied in their metabolic behavior on admission on account of the varying store of vitamin $\mathrm{D}$ acquired prior to the studies. Thus Cases 8 and 9 were deficient in vitamin $\mathrm{D}$, while Case $10 \mathrm{ex}$ hibited evidence of a considerable store when the studies were begun. Cases 8 and 10, under adequate Vigantol therapy and high calcium and phosphorus intake, consistently showed a retention of calcium and phosphorus considerably over and above the requirements of pregnancy, proving that in osteomalacia it is possible for the patients under such a regimen to gain sufficient minerals for the skeletal reparation as well. The mineral retention in Case 9 was not as much as expected, probably due to the inefficient manner of administering vitamin $\mathrm{D}$. When large amounts of calcium and phosphorus are required for the growth of the fetus as well as for the replenishment of the depleted skeleton of the mother, as in Case 8, serum calcium and phosphorus may fail to rise to perfectly normal levels in spite of adequate vitamin $\mathrm{D}$ and high mineral intake.

The behavior that may be said to characterize this group of patients with extensive bone involvement consists of more marked metabolic evidence of vitamin $\mathrm{D}$ deficiency when untreated, unusually high retention of calcium and phosphorus under high mineral and vitamin $\mathrm{D}$ intake, and ocasional failure of the serum calcium and phosphorus to rise to normal in spite of such therapy. 


\section{DISCUSSION}

Quantitative measurements of calcium and phosphorus metabolism in osteomalacia during pregnancy of the type here presented are not available in the literature except for the two cases which have been briefly reported by us (14). Such data are important in evaluating the rôle of pregnancy in the pathogenesis of osteomalacia in view of the frequent association of the two. A comparison of the metabolic behavior during pregnancy of patients with severe or mild osteomalacia with that of subjects showing no skeletal lesions reveals no essential differences. With adequate vitamin D supply and moderately high intake of calcium and phosphorus, subjects of various skeletal condition have no difficulty in retaining sufficient amounts of the minerals for the needs of gestation. In fact, under similar regimen, osteomalacic patients tend to retain more calcium and phosphorus in an attempt to replenish the depleted maternal store, as well as to provide for fetal growth. In other words, there is no inherent inability on the part of osteomalacic patients during pregnancy to utilize calcium and phosphorus in the midst of plenty of these minerals and vitamin D. Whatever metabolic defect they may show during gestation results from limited vitamin D and mineral supply just as it does during reproductive rest.

Furthermore, in contrast to lactation, where the physiological activity is such that mineral requirement has to be increased much above what is secreted in the milk, even in the presence of adequate vitamin $\mathrm{D}$, there is no such factor in pregnancy. Cases 9 and 10 were subsequently observed during lactation and reported on as Cases 1a and $4 \mathrm{a}$ in paper IX of this series (2). In both instances, the mineral balances were much less favorable during lactation than during pregnancy under similar conditions of adequate vitamin D and high calcium intake. Moreover, in Case 5, where the termination of pregnancy was not followed by lactation, mineral retention did not improve after delivery, again showing that pregnancy itself has no excessively deleterious influence on mineral retention.

However, the minimal requirement for fetal growth of $200 \mathrm{mgm}$. calcium and $100 \mathrm{mgm}$. phosphorus per day during the last three months of gestation has to be met through the maternal mineral resources. The usual level of calcuim intake in Chinese dietary is approximately 0.337 gram and that of phosphorus 1.2 grams (15), although somewhat higher levels of intake have been recorded by others. Such a level of calcium intake, in the presence of vitamin $\mathrm{D}$, may maintain an individual in balance under ordinary circumstances, but in pregnancy it cannot be expected to yield adequate mineral balance for the fetal requirement. The extent of drain on the skeletal store of the mother will depend upon her state of vitamin $\mathrm{D}$ nutrition. If there is adequate vitamin D supply-sometimes from the diet, but usually from sunlight (16) -a variable proportion of the total fetal requirement ( 21 to 23 grams of calcium) may have to be drawn from the maternal store. This alone may not constitute a serious loss to the mother. On the other hand, in the absence of vitamin $\mathrm{D}$, the mineral loss will be much greater than that imparted to the fetus. Under such circumstances, pregnancy plays an important rôle in the causation of osteomalacia. Moreover, pregnancy is usually followed by prolonged lactation, which constitutes a much greater drain upon the maternal skeletal store. Such a reproductive cycle frequently repeated under an inadequate supply of calcium and vitamin $\mathrm{D}$ will inevitably lead to the development of osteomalacia.

As to the actual level of calcium that may be considered adequate to meet the needs of gestation, our data do not give a clear-cut answer. In the first subject who was presumably normal from the standpoint of vitamin D nutrition, an intake of 1 gram of calcium was necessary to bring about sufficient retention for the fetal needs. In individuals (Cases 2, 3 and 6) in whom the vitamin D supply was limited, or beginning to be depleted, an intake of 1.0 to 1.3 grams of calcium seemed also adequate for the gestatory requirement. There was evidence that, in the presence of greater supply of vitamin $D$, they could acquire the same degree of retention on an intake level considerably lower than 1.3 grams (Case 3). However, in severe grades of vitamin D depletion, an intake of 1.3 grams, or higher, of calcium would not maintain the individual in balance (Case 4). These data all go to show that vitamin $\mathrm{D}$ is a more important factor than the actual level of 
calcium intake in determining the extent of rentention, provided a reasonable amount of calcium is present in the diet. As to phosphorus, its utilization depends a great deal on that of calcium. As Chinese dietaries contain good amounts of phosphorus, adequate calcium retention usually means adequate phosphorus retention. Likewise, there is apparently no difficulty in nitrogen metabolism with usual Chinese dietaries.

A comparison of the data of these subjects showing varying skeletal condition and vitamin D store with those of presumably normal women in pregnancy available in the literature shows greater degree of mineral conservation in our patients. Toverud and Toverud (17) made short periods of observation on thirty Norwegian women living in a home for expectant mothers during the last two to three months of pregnancy. Negative calcium and phosphorus balances were the rule on the usual home diets, but positive balances were sometimes observed after the intake of calcium and phosphorus had been increased to 1.6 to 2.0 grams. Coons et al. (5) reported the results on 2 groups of women, one in Chicago, the other in Oklahoma. With an average intake of 1.4 grams calcium and 1.6 grams phosphorus, adequate retention for gestatory needs occurred in the Southern women, but not in the Chicago women, the difference being attributed to the influence of sunshine. Macy and Hunscher (4), from a compilation of data in the literature on mineral utilization during pregnancy, concluded that during the last three months an intake of 1.4 to 1.5 grams of calcium and 2 grams of phosphorus was necessary to secure adequate retention for the demands of pregnancy. On the other hand, in our subjects 1.0 to 1.3 grams of calcium seemed adequate for the requirements of pregnancy, even when the supply of vitamin D was limited. With optimum vitamin $\mathrm{D}$ nutrition calcium requirement may be lowered.

This relative conservatism shown by our patients cannot be entirely due to the depleted skeletal store which would cause calcium to be retained with great avidity because the patients in the first group without obvious osseous decalcification exhibited the same phenomenon. Another important factor seems to lie in the previous level of intake. When the dietary habits accustom the subject to a lower intake, the added requirement for reproductive activity will be correspondingly lower. Furthermore, vitamin D plays such an important rôle in conserving calcium that its judicious use will make it possible to decrease the usually quoted requirement for a given state of physiological activity. The combination of previous low level of intake and existing vitamin $\mathrm{D}$ action probably explains the unusual ability on the part of five of the ten subjects in this series to retain calcium on intakes varying from 88 to $277 \mathrm{mgm}$. per day (Cases 3, 4, 6, 7 and 10). It is plain, then, that the so-called calcium requirement, contrary to current conception, must be regarded as a variable quantity conditioned by such factors as the prior skeletal store, the previous dietary custom, and the state of vitamin D nutrition.

\section{SUMMARY}

Data on calcium, phosphorus and nitrogen metabolism during the latter part of pregnancy were obtained on ten subjects showing various states of skeletal store and vitamin D nutrition. Given an adequate supply of vitamin $\mathrm{D}$ and calcium, patients with osteomalacia showed no inherent inability to retain minerals during pregnancy, compared with those with no skeletal depletion. The added requirement during gestation, unlike that in lactation, did not seem to go beyond fetal needs. However, such needs had to be filled at the expense of the maternal tissue, if the supply of vitamin $\mathrm{D}$ and minerals was inadequate. Under such circumstances, pregnancy plays an important pathogenetic rôle in osteomalacia inasmuch as it hastens the skeletal demineralization. While high calcium intake tends to ameliorate the effects of vitamin $\mathrm{D}$ deficiency, the latter conserves calcium. Of the two, vitamin $\mathrm{D}$ is probably more important, provided a reasonable level of calcium intake is available. The calcium requirement during pregnancy is conditioned by the prior skeletal store, the previous dietary intake, and the state of vitamin $\mathrm{D}$ nutrition.

\section{BIBLIOGRAPHY}

1. Liu, S. H., and others, Calcium and phosphorus metabolism in osteomalacia. VI. The added drain of lactation and beneficial action of vitamin D. Chinese J. Physiol., 1937, 11, 271.

2. Liu, S. H., and others, Calcium and phosphorus metabolism in osteomalacia. IX. Metabolic behavior of infants fed on breast milk from mothers show- 
ing various states of vitamin D nutrition. J. Clin. Invest., 1940, 19, 327.

3. Givens, M. H., and Macy; I. C., The chemical composition of the human fetus. J. Biol. Chem., 1933, $102,7$.

4. Macy, I. C., and Hunscher, H. A., An evaluation of maternal nitrogen and mineral needs during embryonic and infant development. Am. J. Obst. and Gynec., 1934, 27, 878.

5. Coons, C. M., and others, Oklahoma Agric., Mech. Coll., Agric. Exp. Stat., Bull. No. 233, 1935.

6. McIlroy, L., Discussion on diet in pregnancy. Proc. Roy. Soc. Med., 1935, 28, 1385.

7. Garry, R. C., and Stiven, D., A review of recent work on dietary requirements in pregnancy and lactation, with an attempt to assess human requirements. Nutrition Abstr. and Rev., 1935-36, 5, 855.

8. Hannon, R. R., and others, Calcium and phosphorus metabolism in osteomalacia. I. The effect of vita$\min \mathrm{D}$ and its apparent duration. Chinese M. J., 1934, 48, 623.

9. Liu, S. H., and others, Calcium and phosphorus metabolism in osteomalacia. III. The effects of varying levels and ratios of intake of calcium to phosphorus on their serum levels, paths of excretion and balances. Chinese J. Physiol., 1935, 9, 101.

10. Liu, S. H., and others, Calcium and phosphorus metabolism in osteomalacia. V. The effect of varying levels and ratios of calcium to phosphorus intake on their serum levels, paths of excretion and balances, in the presence of continuous vitamin D therapy. J. Clin. Invest., 1937, 16, 603.

11. Chu, H. I., and others, Calcium and phosphorus metabolism in osteomalacia. X. Further studies on vitamin $D$ action: early signs of depletion and effect of minimal doses. J. Clin. Invest., 1940, 19, 349.

12. Gunnarson, S., Treatment of rickets with a single massive dose of vitamin $D_{2}$. Acta. Paediat., 1939, $25,69$.

13. Liu, S. H., and others, Unpublished data.

14. Liu, S. H., and others, Calcium and phosphorus metabolism in osteomalacia. II. Further studies on the response to vitamin $\mathrm{D}$ of patients with osteomalacia. Chinese M. J., 1935, 49, 1.

15. Wu, H., and Wu, D. Y., Study of dietaries in Peking. Chinese J. Physiol. (rep. ser.), 1928, no. 1, 135.

16. Chu, H. I., and others, Calcium and phosphorus metabolism in osteomalacia. VII. The effect of ultraviolet irradiation from mercury vapor quartz lamp and sunlight. Chinese M. J., 1939, 55, 93.

17. Toverud, K. U., and Toverud, G., Studies on the mineral metabolism during pregnancy and lactation and its bearing on the disposition to rickets and dental caries. Acta. Paediat., 1931, 12, supp. II.

18. Liu, S. H., The rôle of vitamin D in the calcium metabolism in osteomalacia. Chinese M. J., 1940, 57, 101. 